\title{
Persimpangan Antara Agama dan Budaya (Proses Akulturasi Islam dengan Slametan dalam Budaya Jawa)
}

\author{
Ryko Adiansyah \\ Fakultas Ilmu Tarbiyah dan Keguruan \\ Universitas Islam Negeri Raden Fatah Palembang \\ E-mail: rykoadiansyah_uin@radenfatah.ac.id
}

\begin{abstract}
Abstrak
Konsep slametan berakar dari budaya asli Jawa yaitu diawali dengan bekeyakianan animisme dan dinamisme yang pada dasarnya adalah keyakinan nenek moyang, dan selanjutnya dihidupkan dan diperkaya oleh budaya Hindu dan Buddha yang mempercayai adanya dewa-dewa yang berwujud benda-benda dan kejadian alam. Masuknya Islam di Jawa menggunakan pola "damai" dengan persuasi sehingga masih terdapat simbol-simbol budaya masa lalu yaitu animisme-dinamis, Hindu-Buddha yang masih menjadi "pola" pikir dan paradigma masyarakat Jawa. Slametan adalah konsep universal yang di setiap tempat pasti ada dengan nama yang berbeda dan bermacam cara pula. Hal ini karena kesadaran akan diri yang "lemah" di hadapan kekuatan-kekuatan di luar diri manusia. Di Jawa Kuno, kekuatan diri adalah kekuatan benda dan ruh nenek-moyang yang pada saat Islam datang ditranformasikan pada selamat dari kekuatan Tuhan yang dapat merugikan diri manusia.
\end{abstract}

Kata Kunci: Agama, Budaya, Slamatan.

Agama secara mendasar dapat didefenisikan sebagai perangkat, aturan, peraturan atau undang-undang dalam mengajur hubungan manusia dengan dunia goib, baikepada sang Penciptanya, Para Malaikat, bahkan mahluk ciptaan yang tidak dapat dilihat oleh manusia. Serta mengatur hubungan antara manusia dengan manusia lainnya dan manusia dengan alam sekitarnya. Namun dalam defenisi ini keterliatan manusia sebagai pendukung atau atau penganut agama tidak nampak didalamnya, karena agama adalah dinilai sebagi teks atau dokrin semata (Turmudzi, 2010, h. 179).

Masalah-masalah yang berhubungan dengan agama baik dalam kehidupan perindividual, kelompok, maupun masyarakat umum, pengetahuan dan berkeyakinan keagamaan yang berbeda dari pengetahuan dan keyakinan lainnya yang dimiliki manusia, fungsi keyakinan keagamaan terhadap kehidupan duniawi dan sebaliknya. Berbicara tentang fenomena keagamaan memang tidak sederhana, karena sifatnya yang multifisial. Sebagai suatu sistem, kensep religi, dapat dibagi ke dalam beberapa bagaian, seperti: (a). Emosi Keagamaan, (b). Berkeyakinan, dan (c). Sitem Ritus dan Upacara. Bagian-bagian ini dirangkum dalam pokok-pokok pikiran manusia serbagai sikap masyarakat terhadap agama tersebut. Dikatakan demikian karena presepsi manusia ikut memainkan peran dalam melihat apa sesungguhnya agama itu. Orang berusaha mencari relevansi agama dalam kebutuhan zaman dan masyarakat yang selalu berubah. Ketika presepsi ikut mewarnai agama disitulah batas-batas agama dan kebudayaan menjadi kabur.

Agama sebagai sistem keyakinan dapat menjadi bagian dan inti dari sestem-sistem nilai yang terkandung dalam kebudayaan dari masyarakat yang berhubungan langsung 
dan menjadi stimulator atau penggerak serta pengontrol bagi tindakan-tindakan para anggota masyarakat untuk tetap berjalan sesuai dengan nilai-nilai kebudayaan dan dokrin agamanya. Dengan demikian, secara langsung atau tidak langsung etos yang menjadi pedoman dari keberadaan dan kegiatan berbagai intitusi yang ada dalam masyarakat dipengaruhi dan digerakkan oleh berbagai sistem nilai yang sumbernya adalah agama yang diperlukannya. Hal ini terwujud dalam kegiatan masyarakat. Tindakan dan kegiatan atau karya-karya yang diselimuti oleh simbol-simbol suci inilah yang dinamakan kebudayaan.

Demikian pula dalam pembicaraan mengenai kebudayaan juga tidak kalah rumitnya. Penafsiran dan memahami kata kebudayaan disebabkan adanya keterlibatan adanya prasangka yang kuat dalam paradikman kebudayaan. Pada dasarnya masarakat adalah "pasien" dari sebuah kebudayaan sebelum diantara mereka cukup kuat untuk menjadi "agen” budaya tersebut (Lubis, 2011, h. 836).

Pemahaman dan pendalaman mengenai adanya berbagai proses resepsi agama dalam kebudayaan memberikan peluang lebih besar untuk terjadinya antar umat atau masyarakat di sekitarnya, terjalinnya sistem kegotong royongan dalam diri masyarakat yang mempunyai lingkup tradisi. Hal semacam inilah lama kelamaan akan menjadi kebudayaan dalam masyarakat yang akan menciptakan suatu peraturan atau sanksi dalam pribadi manusia tersebut.

Kebudayaan merupakan hasil karya manusia dan pemikiran manusia untuk diperbaiki, mengindahkan, dan meningkatkan kualitas kehidupan dalam masyarakat. Kebudayaan merupakan gabungan dari pikiran, kata, dan tingkah laku manusia yang dimamfaatkan untuk berinteraksi dalam masyarakat sekitarnya atau lingkungan sosial. Kebudayaan pada dasarnya mengalami perkembangan selaras ataupun mengikuti arus adaptasi lingkungan disekitarnya, atau pelaku kebudayaan yang berperan aktif di dalamnya.

Kebudayaan diketahui karena adanya karya-karya atau kandungan-kandungan yang terdapat didalamnya. Kandungan-kandungan terus menerus akan bertambah dan berkembang dalam kehidupan manusia. Perkembangan yang dilakukan manusia akan berakibat pula pada perkembangan budaya. Manusia disebut mahluk agen budaya, jika manusia mampu hidup dalam agen budaya atau aturan-atauran dalam budaya. Sebagai mahluk berbudaya, bukan saja sebagai pelestari nilai-nilai kebudayaan yang dihasilkan manusia sebelumnya atau dikenal sejarah nenek moyang, melainkan termasuk melestarikan karya-karya kebudayaan.

Manusia pada kelompoknya, dalam kelompoknya mempunayi aturan-aturan atau norma, nilai-nilai yang dianggap sakral, serta adat kebiasaan yang diwariskan secara turun-temurun yang dikenal dengan warisan tradisi. Warisan tradisi biasanya diwariskan secara turun temurun dan ini diipertahankan, manu terkadang mengalami penyempurnaan akibat pengaruh dari luar kedalam kelompok kebudayaan itu berada dan berkembang. 
Misalnya, adanya pengaruh keagamaan dalam kelompok masyarakat yang melestarikan budaya tersebut Penggunaan Kemian dalam acara persedekahan atau sedekah ruah (Forum Rektor Indonesia Simpul Jawa Timur, 2003, h. 186) di bungkus dengan kemasan keagamaan sehingga menghasilkan karya-karya atau singkretis antara agama dan kebudayaan.

Kebudayaan dan berbudaya, sesuai dengan pengertiannya, tidak pernah berubah; yang mengalami perubahan dan perkembangan adalah hasil-hasil atau unsur-unsur kebudayaan. Namun, ada kecenderungan dalam masyarakat yang memahami bahwa hasil-hasil dan unsur-unsur budaya dapat berdampak pada perubahan kebudayaan.

Kecenderungan tersebut menghasilkan dikotomi hubungan antara iman-agama dan kebudayaan. Dikotomi tersebut memunculkan konfrontasi (bukan hubungan saling mengisi dan membangun) antara agama dan praktek budaya, karena dianggap sarat dengan spiritisme, dinamisme, animisme, dan totemnisme. Akibatnya, ada beberapa sikap hubungan antara Agama dan Kebudayaan, yaitu:

1. Sikap Radikal: Agama menentang Kebudayaan. Ini merupakan sikap radikal dan ekslusif, menekankan pertantangan antara Agama dan Kebudayaan. Menurut pandangan ini, semua sikon masyarakat berlawanan dengan keinginan dan kehendak Agama. Oleh sebab itu, manusia harus memilih Agama atau/dan Kebudayaan, karena seseorang tidak dapat mengabdi kepada dua tuan. Dengan demikian, semua praktek dalam unsur-unsur kebudayaan harus ditolak ketika menjadi umat beragama.

2. Sikap Akomodasi: Agama Milik Kebudayaan. Sikap ini menunjukkan keselarasan antara Agama dan kebudayaan.

3. Sikap Perpaduan: Agama di atas Kebudayaan. Sikap ini menunjukkan adanya suatu keterikatan antara Agama dan kebudayaan. Hidup dan kehidupan manusia harus terarah pada tujuan ilahi dan insani; manusia harus mempunyai dua tujuan sekaligus.

4. Sikap Pambaharuan: Agama Memperbaharui Kebudayaan. Sikap ini menunjukkan bahwa Agama harus memperbaharui masyarakat dan segala sesuatu yang bertalian di dalamnya. Hal itu bukan bermakna memperbaiki dan membuat pengertian kebudayaan yang baru; melainkan memperbaharui hasil kebudayaan.

Jika umat beragama mau mempraktekkan unsur-unsur budaya, maka perlu memperbaikinya agar tidak bertantangan ajaran-ajaran Agama. Karena perkembangan dan kemajuan masyarakat, maka setiap saat muncul hasil-hasil kebudayaan yang baru. Oleh sebab itu, upaya pembaharuan kebudayaan harus terus menerus. Dalam arti, jika masyarakat lokal mendapat pengaruh hasil kebudayaan dari luar komunitas sosio-kulturalnya, maka mereka wajib melakukan pembaharuan agar dapat diterima, cocok, dan tepat ketika mengfungsikan atau menggunakannya. Karena adanya aneka ragam bentuk hubungan Agama dan Kebudayaan tersebut, maka solusi terbaik adalah perlu pertimbangan-pengambilan keputusan etis-teologis (sesuai ajaran agama). Dan untuk mencapai hal tersebut tidak mudah. 
Kebudaya yang lebih tinggi atau yang mendominan dan aktif dalam masyarakat tersebut akan mempengaruhi budaya yang lebih rendah dan pasif melalui kontak budaya (Winarno, 2011, h. 78). Teori Malinowski ini sangat nampak dalam pergeseran nilai-nilai budaya bangsa yang cenderung dipengaruhi oleh budaya Barat. Dalam era globalisasi informasi akan berpengaruh kuat dalam mempengaruhi pola pikir manusia. Budaya Barat saat digambarkan dengan modernitas (modernisasi), dan budaya timur diidentikkan dengan tradisional atau konvensional.

. Sementara itu, ia justru menemukan Mc. Donald's, Kentucky Fried Chicken, Pizza Hut, dan Dunkin Donuts di sini. Beberapa toserba dan pasar swalayan juga mirip seperti yang ia temukan di luar negeri dengan penataan yang serupa. Kedua tempat berbelanja tersebut bahkan lebih banyak menggunakan petunjuk-petunjuk berbahasa Inggeris, meskipun mayoritas pengunjungnya adalah orang Melayu. Ia melihat banyak pemuda bergaya masa kini, dengan rambut panjang di buntut kuda, sebelah telinganya beranting, bercelana Levi's duduk-duduk santai di Mall, seraya meneguk minuman dingin 'Soft Drink'. Demikian pula pemuda-pemudinya banyak sekali yang hanya menggunakan kaos sepotong yang ketat dan tidak sempat menutup pussarnya, dengan celana panjang yang ketat pula, sedangkan rambutnya disisir dengan gaya semrawut. Di kota-kota besar sudah tumbuh pub-pub, night-club, diskotik dan karaoke yang sangat laris. Restoranrestoran yang menyediakan makanan ala China, dan Eropa.

Sinkronisasi Budaya menyatakan "lalu lintas produk budaya masih berjalan satu arah dan pada dasarnya mempunyai mode yang sinkronik. Negara-negara Metropolis terutama Amerika Serikat menawarkan suatu model yang diikuti negara-negara satelit yang membuat seluruh proses budaya lokal menjadi kacau atau bahkan menghadapi jurang kepunahan". Dimensi-dimensi yang unik dari budaya Nusantara dalam spektrum nilai kemanusiaan yang telah berevolusi berabad-abad secara cepat tergulung oleh budaya mancanegara yang tidak jelas manfaatnya.

Ironisnya hal tersebut justru terjadi ketika teknologi komunikasi telah mencapai tataran yang tinggi, sehingga kita mudah melakukan pertukaran budaya. hal ini terjadi biasanya melalui media masa, secara langsung kurangnya kesadaran untuk menyaring kedatangan budaya Barat tersebut. Hamelink juga mengatakan, bahwa dalam sejarah budaya manusia belum pernah terjadi lalu lintas satu arah dalam suatu konfrontasi budaya seperti yang kita alami saat ini. Karena sebenarnya konfrontasi budaya dua arah di mana budaya yang satu dengan budaya yang lainnya saling pengaruh mempengaruhi akan menghasilkan budaya yang lebih kaya (kompilasi) (Achmad, 2004, h. 14-15). Sedangkan konfrontasi budaya searah akan memusnahkan budaya yang pasif dan lebih lemah. Menurut Hamelink, bila otonomi budaya didefinisikan sebagai kapasitas masyarkat untuk memutuskan alokasi sumber-sumber dayanya sendiri demi suatu penyesuaian diri yang memadai terhadap lingkungan, maka sinkronisasi budaya tersebut jelas merupakan ancaman bagi otonomi budaya masyarakatnya. 
Dalam beberapa teori diatas, dapat disimpulkan bahwa pengaruh budaya besar akan berdampak pada budaya yang lemah. Perkembangan itu bisa diakibatkan melalui keturunan (nenek moyang) dalam hal ini dapat dikaitkan dengan masyarakat Jawa, ataupun melaui media masa seperti halnya budaya Barat yang masuk ke Indonesia. arus globalisasi ini, tidak dapat dipungkiri kapan dan bagaimana terjadinya, hal ini biasanya mengalir dengan sendirinya.

Agama Islam adalah pengaruh besar dalam masyarakat Jawa, namun tradisi dan adat kebiasaan masyarakat Jawa yang tidak dapat dihilangkan dan tetap tertanan di dalam diri masyarakat. Hal ini sangat sulit dihilangkan, namun dengan cara mengklabolirasi antara budaya Jawa (nenek moyang) dengan ajaran Islam dilakukan para wali untuk bisa masuk ke dalam masyarakat Jawa pada waktu itu. Maka hal inilah yang masih berkembang dalam masyarakat Jawa.

Tujuan dalam penelitian merupakan dapat mengetahui antara ajaran Islam ynag murni dan ajaran Islam dalam kombinasi budaya Jawa, dalam kontek ini yaitu mengenai Proses Akulturasi Islam dengan Slametan dalam Budaya Jawa. Sehingga masyarakat dapat mengetahui bahwa agama adalah berbudaya dan budaya buanlah agama, adapat lebih mengsakralkan makna agama dibandingkan maknah budaya (nenek moyang).

\section{Manfaat Agama dalam Perkembangan Kebudayaan}

Secara Fungsional sosial, timbal-balik antara agama dan kebudayaan lebih menitik beratkan pada aspek-aspek yang bersifat rasional dan humanis, atau secara sosial karitatif dalam wilayah masyarakat, hal idi biasanya disebut dengan Historical Force yang berperan aktif dalam terjadinya perubahan dan perkembangan suatu masyarakat.

Mengenai hal ini, dapat disimpulkan bahwa agama mampu menjadi jembatan mengurangi terjadinya disintegrasi dalam kehidupan masyarakat. Bahkan lebih dari itu, dengan kemapuan yang ada didalamnya, agama dapat dijadikan pondasi dalam pembangunan spritual yang memberi penopang dan memberi jalan dalam menyelesaikan persoalan sosial, mengatasi rasa kurang percaya diri sosial, pembudakan dan kemiskinan.

Menurut Peter L Berger mengemukakan hal yang sama, bahwa agama merupakan sistem simbolik yang memberikan makna dalam kehidupan manusia yang bisa memberikan penjelasan secara meyakinkan, serta paling komprehensif tentang realitas, tragedi sosial dan penderitaan atau rasa ketidakadilan.

Dari penjelasan diatas, memahami agama sebagai bagian dari gejala kebudayaan tentu bersifat kontektual, yaitu fenomena keagamaan yang terjadi dalam masyarakat merupakan bagian dari kehidupan sosial secara kultural. Menyikapi fenomena ini agama di fungsikan pada rana pemahaman individu yang memandangnya dan mendalaminya, baik dalam bentuk inividual ataupun dalam bentuk kelompok atau sosial masyarakat. Setiap agam atau kepercayaan, tentu mengajarkan nilai-nilai, norma-norma, ataupun aturan-aturan yang terkandung didalamnya, untuk mengatur jalanya kehidupan si 
pemeluk agam atersebut, walaupun pada hakikatnya sumber agama itu terdiri dari nilainilai yang bersifat transendental.

Keyakinan keagamaan yang demikian, oleh Berger dikatakan dapat membentuk masyarakat kognitif, memberi kemungkinan bagi agama untuk berfungsi menjadi pedoman dan petunjuk bagi pola tingkah laku dan corak sosial. Dari hal inilah, agama dapat dijadikan sebagai instrumen integratif bagi kehidupan masyarakat dalam suatu wilayah. Pada dasarnya agama juga berbentuk wujud pebuatan manusia dan pengatur sistem sosial.

Seorang Intelektual Soedjatmoko juga mengakui agama menjadi penggerak dan pemersatu masyarakat secara efektif. Karena, agama lebih dari ideologi sekuler mana pun, merupakan sistem integrasi yang menyeluruh. Agama mengandung otoritas dan kemampuan pengaruh untuk mengatur kembali nilai-nilai dan sasaran-sasaran yang ingin dicapai masyarakat. Dengan demikian, fungsi sosial agama adalah memberi kontribusi untuk mewujudkan dan mengekalkan suatu orde sosial (tatanan kemasyarakatan). Secara sosiologis memang tampak ada korelasi positif antara agama dan integrasi masyarakat; agama merupakan elemen perekat dalam realitas masyarakat yang pluralistik.

\section{Slametan dalam Kosmologi Jawa}

Indonesia merupakan negara kepulauan yang sangat luas dan besar, terdiri dari lima pulau besar yaitu Pulau Sumatera, Pulau Jawa, Pulau Kalimantan, Pulau Sulawesi, dan Pulau Papua. Adapun letak geografis Indonesia berada diantara dua benua yaitu Benua Asia dan Benua Australia, dan juga diapit oleh dua samudera yaitu Samudera Hindia dan Samudera Pasiflik, hal inilah yang menyebabpakn Indonesia sebagai jalur perekomonian dunia.

Secara geografis, negara Indonesia berada dan berdomisili di lingkungan wilayah yang memiliki garis-garis pantai dan hutan tropis, yang tersebar di kawasan seluas hampir 3.000 mil. Dari faktor wilayah, Indonesia memiliki lebih dari 13.000 pulau yang bertebaran sepanjang garis katulistiwa. Sehingga pada gilirannya, kedua faktor tersebut, secara tidak lansung telah membentuk kemajemukan bangsa ini dalam berbagai hal, baik dalam tradisi-sosial, suku-ras, bahasa, maupun agama dan kepercayaan. Keadaan geografis dan wilayah yang dimiliki Indonesia ini telah membentuk keragaman dan perbedaan struktur masyarakatnya.

Dari jumlah seluruh masyarakat Indonesia mayoritas beragama Islam menurut Andullah (2006, h. 19), bahwa hampir $85 \%$ penduduk beragama Islam, umat Islam di Indonesia tersebar ke pelosok Nusantara. Dari jumlah yang mayoritas tersebut, masyarakat Islam menjadi sebuah niali panutan dan dijunjung oleh masyarakat Indonesia. Islam sebagai sebuah agama yang merefleksikan sikap sentral budaya masyarakat di Indonesia. Beberapa peraturan atau hukum dalam pemerintahan dan negara banyak yang terinspirasi dengan hukum Islam. Selian itu, Islam menjadi satu budaya yang menyatu 
dengan budaya asli Indonesia. Sebagai negara dengan mayoritas muslim yang terbesar di seluruh wilaya Nusantara, Indonesia tentu harus menentukan peran terhadap Islam itu sendiri. Negara Indonesia sebagai suatuu sistem yang memiliki kekuasaan tertinggi dan sah, sepatutnya menjamin hak-hak kaum muslimin. Dalam pemenuhan hak-hak itu timbullah peran negara Indonesia yang menjamin rakyatnya yang merupakan kaum muslimin.

Pulau Jawa atau Java pada masa kolonial, sebutan lain seperti Djawa Dwipa atau Djawi adalah pulau yang yang pada dasarnya bila diukur dari titik terjauh, memiliki panjang lebih dari $1.200 \mathrm{~km}$, dan memiliki lebar $500 \mathrm{~km}$. Pulau ini terletak di tepi selatan kepulauan Indonesia, kurang lebih tujuh derajat sebelah selatan garis katulistiwa. Karakter khas pulau ini adalah formasi geologi tua yang dimilikinya, berupa deretan pegunungan dari Himalaya dan Pegunungan Asia Tenggara. Luas pulau ini hanya 7\% dari seluruh wilayah kepulauan Indonesia. Tetapi anehnya, dia memiliki penduduk hampir $60 \%$ dari seluruh penduduk Indonesia.

Pada dasarnya, yang dikenal dengan sebutan orang Jawa menurut Suseno adalah orang yang memakai bahasa Jawa sebagai bahasa ibu dan merupakan penduduk asli bagian tengah dan timur pulau Jawa. Sementara, menurut Tony Whitten, sebagaimana dikatakan oleh Roehayat Soeriatmadja dan Suraya Afiff, The Ecology Java and Bali mengatakan bahwa penduduk asli pertama Pulau Jawa adalah mirip dengan suku Aborigin di Australia. Mereka disebut Austroloid. Namun demikian, kemudian mereka tersingkir oleh pendatang dari Asia Tenggara. Mereka tidak dapat hidup di Jawa, tetapi saat ini keturunan mereka dapat ditemukan di suku Anak Dalam atau Kubu di Sumatera Tengah atau di Indonesia bagian timur.

Berbeda halnya dengan Kunjaranigrat yang menyatakan orang Jawa adalah bahwa pada sekitar 3.000-5.000 tahun lalu arus pendatang selanjutnya yang disebut proto-Malay datang ke Jawa. Keturunan mereka saat ini dapat dijumpai di Kepulauan Mentawai, Sumatera Barat, Tengger di Jawa Timur, Dayak di Kalimantan, dan Sasak di Lombok. Setelah itu, gelombang pendatang yang disebut Austronesia atau Deutro-Malay yang berasal dari Taiwan dan Cina Selatan datang melalui laut ke Pulau Jawa, sekitar 1.0003.000 tahun silam. Sekarang keturunannya banyak tinggal di Indonesia bagian Barat dengan keahlian bercocok tanam padi, pengairan, membuat barang tembikar atau pecah belah, dan kerajinan dari batu.

Membicarakan konsep slametan dalam budaya masyarakat Jawa, akan berhubungan erat dengan pembahsan mengenai pemahaman atau kepercayaan yang menjadi pandangan hidup dalam keseharian masyarakat Jawa. Ketika mengupas persoalan kepercayaan tradisi masyarakat Jawa, hal ini akan berhadapan dengan hamparan luas sejarah keyakianan yang sudah ada sejak nenek moyang, wajar saja karena yang berkaitan dengan kepercayaan atau agama mempunyai usia yang cukup tua dengan eksistensi keyakiana manusia yang meyakininya. Hal ini menjadi menarik karena pembahasan tentang adat kebudayaan erat hubungannya dengan kepercayaan dan nilai- 
nilai yang terkandung didalamnya. Oleh karena itu, seringkali tradisi berkembang atas dasar keyakinan dan nilai-nilai yang tertanam didalamnya.

Kondisi kehidupan "keagamaan" masyarakat Jawa sebelum datangnya agama Islam sangatlah heterogen. Kepercayaan yang datang dari luar Jawa ataupun kepercayaan yang ada di dalam masyarakat Jawa telah berkembang dan diyakini selama beribu-ribu tahun lamanya dalam kehidupan masyarakat Jawa. Sebelum agama Hindu dan agama Buddha berkembang dalam masyarakat Jawa, masyarakat prasejarah yang ada di Jawa telah mempunyai keyakianan yang bercorak animisme dan dinamisme (Kusumohamidjojo, 2010, h. 78). Filasafat hidup orang jawa dalah mengarah pada pembentukan persatuan nominous antara alam nyata, masyarakat, dan alam adikodrati yang disakralkannya.

Romdlon (Kusumohamidjojo, 2010, h. 100) animisme adalah aliran (doktrin) kepercayaan yang mempercayai realitas (eksistensi, maujud) jiwa (roh) sebagai daya kekuatan yang luar biasa yang bersemayam secara mempribadi di dalam manusia, binatang, tumbuh-tumbuhan, dan segala yang ada di alam raya ini.

Melalui kepercayaan atau keyakinan ini, akan melahirkan penyembahan terhadap roh-roh nenek moyang. Mengagungkan ruh pada masyarakat akan melahirkan tradisi dan ritual yang dilakukan untuk menghormati ruh nenek moyang, hal ini dilakukan dengan menyediakan atau melakuakan korban baik itu berupa sesajian dan selamatan. Tujuan pemujaan ini adalah sebagai perwujudan permohonan pada ruh-ruh yang dianggap suci untuk dapat memberikan keselamatan dan menghindari dari murkanya ruh-ruh tersebut. Hal ini biasanya diiringi dengan Seni pewayangan dan gamelang sebagai bagian dari ritual yang seringkali dijadikan sarana untuk mengundang dan mendatangkan ruh nenekmoyang. Dalan tradisi ritual ini, ruh nenek-moyang dipersonifikasikan sebagai punakawan yang memiliki peran pangemong keluarga yang masih hidup.

Kata Sajen secara bahasa adalah makanan (bunga-bungaan dan sebagainya) yang disajikan untuk makhluk halus. Sajen adalah satu bentuk laku spiritual. Sebagaimana diketahui, seseorang tidak ingin mendapatkan gangguan apa pun dalam kehidupannya. Seseorang selalu ingin hidup yang diwarnai oleh harmoni. Dalam tujuan menggapai harmoni inilah sebagian manusia lantas melakukan laku spiritual sajen. Dengan laku spiritual tersebut, diharapkan yang mbaurekso (menguasai) tempat tertentu tidak mengganggu mereka, menimpakan malapetakan dan bencana.

Dengan demikian, akan tercipta kehidupan yang penuh harmoni. Itulah filosofi orang-orang yang melakukan laku spiritual dalam bentuk sajen. Filosofi ini tentu berakar pada kepercayaan animisme, yaitu sebuah paham yang mendasarkan keyakinan pada peranan makhluk halus atau roh-roh (anima). Makhluk halus atau roh-roh inilah yang sering dibahasakan dengan sebutan yang mbaurekso: Kanjeng Ratu Kidul, Nyai Roro Kidul, dan sebagainya. Sering dibahasakan pula dengan istilah 'penunggu'. Apabila di 
satu tempat keadaannya angker dan mistis, orang-orang di sekitar tempat itu mengatakan bahwa tempat tersebut ada penunggunya.

Sementara dinamisme atau dinamistik adalah doktrin kepercayaan yang memandang bahwa benda-benda alam mempunyai kekuatan keramat atau kesaktian yang tidak mempribadi, seperti pohon, batu, hewan, dan manusia. Dengan kata lain, sebagaimana dikatakan Alisyahbana (Gazalba. 1975. 17). Kepercayaan masyarakat Jawa pra-Hindu Budha adalah keyakinan akan hal-hal ghaib (tak terlihat), besar dan menakjubkan. Mereka menaruh harapan agar tidak diganggu oleh kekuatan tersebut, apalagi mencelakakannya.

Kedudukan ruh dan kekautan benda-benda tersebut diyakini dapat memberikan dampak positif atau keselamatan bahkan sebaliknya. Masyakata Jawa nenek moyang meyakini bahwa benda-benda memiliki kekuatan dan ruh. Hal ini diyakini oleh masyarakat Jawa akan mengakibatkan kemarahan pada kekuatan-kekuatan ataupun ruhruh pada benda-benda tersebut (musibah) yang dapat mengancam keberadaan manusia. Di samping itu, mereka meyakini kekuatan magis keris, tombak, dan senjata lainnya. Benda-benda yang dianggap keramat dan memiliki kekuatan magis ini selanjutnya dipuja, dihormati, dan mendapat perlakuan istimewa.

Datangnya agama Hindu dan Buddha, pada dasarnya tidak bisa menghilangkan keyakianan yang telah ada dalam masyarakat Jawa pada umumnya. Agama aslinya tetap ada, tetapi justru justru menjadi mengalami kesempurnaan dan keselarasan dalam perkembangannya. Hal ini disebabkan, bahwa agama Hindu Buddha menampilkan konsep baru dengan mentranspormasikan kepercayaan masyarakat akan menyakini adanya kekuatan yang ada pada benda dan ruh leluhur menuju pada kekuatan figur-figur tertentu, yakni pada raja-raja. Mereka meyakini bahwa raja adalah titisan para dewa, dari sini akan memunculkan kebudayaan untuk pada raja.

Ketika datangnya agama Islam di Jawa mempunyai peran besar, dimulai dari peralihan keyakinan dari meyakini ajaran agama Hindu Buddha ke dalam nilai-nilai yang mengajarkan ketauhidan yaitu agama Islam. Tranformasi ini diperkasai para raja yang juga berkeyaninan agama Islam. Menyebarkan secara menyeluruh agama Islam di Pulau Jawa dilakukan oleh para Wali Songgo, yang berdakwa dan mendirikan tarekat-tarekat, corak Islam yang menyebar pi Pulau Jawa adalah bercorak ajaran Tasawuf, sementara itu filsafat hidup orang Jawa, hal ini menunjukan keyakinan masyarakat jawa yang selaras dengan keyakinan sebelum datangnya Islam bahkan agama Hinddu dan Buddha.

Dalam pemaparan diatas, bahwa sekalipun tela mengalami tranformasi kepercayaan yang sangat panjang, mulai dari berkeyakinan animisme dan dinamisme, mengalami tranformasi kedua yang dimulai lahirnya agama Hindu dan Buddha dalam waktu yang cukup lama, hingga datangnya agama Islam yang mengajarkan akan ketauhidan, dalam hal ini di masyarakat jawa Islam bercorak Tasawub, namun sebagian 
besar masyarakat Jawa yang pedalaman masih berkembang pesat akan keyakinan bersifat mistik yang mempercayai hal-hal bersifat supranatural.

Menurut Pemberton ada dua fokus geologis utama kekuatan magis dan kekuatan supranatural di Jawa Tengah bagian selatan, yakni, pertama, Gunung Lawu di utara, dan Parangtritis di tepi Samudera Hindia di selatan. Gunung Lawu dianggap sebagai lokasi menghilangnya secara asketik ( $m u k s a$ ) Raja Majapahit terakhir, Brawijaya V. Di samping itu, Gunung Lawu adalah wilayah kekuasaan raja lelembut Sunan Lawu. Sementara itu, Parangtritis adalah suatu tempat yang menghadap ke kerajaan Ratu Kidul, ratu makhluk halus, yang disebut sebagai pasangan spiritual raja-raja Jawa.

Melalui kepercayaan-kepercayaan tersebut, disamping menyediakan sesajian dan slamatan, akan berkaitan dengan upaya-upaya lain, yakni adanya pemagaran kraton dengan pusaka yang diyakini dapat menangkal datangnya bahaya yang mengancam keselatana masyarakat. Pemagaran dilakukan terutama dalam keadaan yang krisis, yakni pada saat terjadinya bencana baik berupa kelaparan, gunung meletus, bahkan dalam halhal yang bersifat penomena alam (Turmudzi, 2010, h. 177).

Kraton adalah melambangkan sumber keselamatan dan melambangkan kesejahteraan, hal ini digambarkan bahwa Kraton sebagai pusat kosmos dan semesta. Kekutan-kekuatan yang sakral disimbolkan pada Kraton menyebar ke seluruh penduduk melaui prosesi ritual dan adanya upacara sakral. Kekuatan-kekuatan rasa dianggap tersimpan dalam pusaka-pusaka yang menjadi pagar atau pelindung di Kraton tersebut. Dapat diketahui dengan adanya Kreta Kencana yang bernama Kereta Ki Mojo di Kraton Yokyakarta, adanya Keris Mpu Gandring Sebagai Pusaka masyarakat Jawa, bahkan hal ini juga terjadi di luar Jawa.

Perlakuan terhadap benda-benda sakaral atau keramat, akan diperlakukan layaknya seorang raja. Adanya penjamasan pusaka kerajaan dilakuakn agar pusakapusaka tersebut tidak menimbulan bencana atas kemurkaan sang pemilik pusaka yang diyakini kekuatan supranaturalnya ada di dalam pusaka yang digunakannya, hal ini diyakini masyarakat Jawa akan menimbulan kehancuran atau bencana. Perlakuan khusus dengan cara mengarak, menjamas, adalah aktifitas yang setiap tahun harus dilaksanakan secara formal oleh masyarakat Jawa, khususnya yang masi memiliki tali ikatan dengan Kraton.

\section{Konsep Slametan dalam Masyarakat Jawa}

Slametan berasal dari kata slamet dalam bahasa Arab: salamah yang berarti selamat, bahagia, sentausa. Selamat dapat dimaknai sebagai keadaan lepas dari insideninsiden yang tidak dikehendaki. Menurut Clifford Geertz (Tilaar, 2002, h. 27). Slamet berarti gak ana apa-apa (tidak ada apa-apa), atau lebih tepat "tidak akan terjadi apa-apa" (pada siapa pun). Konsep tersebut dimanifestasikan melalui praktik-praktik slametan. Slametan adalah kegiatan-kegiatan komunal Jawa yang biasanya digambarkan oleh 
ethnografer sebagai pesta ritual, baik upacara di rumah maupun di desa, bahkan memiliki skala yang lebih besar, mulai dari tedak siti (upacara menginjak tanah yang pertama), mantu (perkawinan), hingga upacara tahunan untuk memperingati ruh penjaga. Dengan demikian, slametan merupakan memiliki tujuan akan penegasan dan penguatan kembali tatanan kultur umum. Di samping itu juga untuk menahan kekuatan kekacauan (talak balak).

Slametan yang dilakukan per individu ataupun hanya dilakukan oleh anggota keluarga saja merupakan slamatan bentuk kecil, hal ini biasanya dapat diilihat dalam slamatan pendirian rumah, menempati tempat baru, dan sebagainya. Sedangkan slametan yang dilakukan dalam skala besar dapat kita lihat ketika danya slamatan desa, membersikan pemakaman umum, bahan dalam adat pernikahan yang dalam hal ini dihadari atau dilakukan oleh masyarakat desa. Menurut Pamberton "praktik yang sarat dengan makna slametan dengan sajen (sesaji) tersebut dilaksanakan dengan maksud agar dapat membangun kembali hubungan dengan roh, terutama dengan ruh penunggu dusun (dhanyang). Dengan kata lain, bersih desa bertujuan untuk menjalin hubungan damai dengan dunia ruh setempat."

Dari pemaparan diatas dapat dipahami, bahwa slamatan merupakan pesta komunal sebagaimana yang dijelaskan diatas pada dasarnya slamatean sering dilakukan dalam skala besar. Namun slametan dengan skala besar justru tidak menunjukkan nilainilai kebersamaan, tetapi yang tanpak adalah justru pesta ritual pembagian "oleh-oleh" yang biasanya oleh masyarakat Jawa berbentuk jajanan atau kueh ringan. Yang menarik dalam slamatan tersebut adalah bukan untuk menunjukkan rasa kegotongroyangan dalam diri masyarakat namun yang ada dalam diri mereka adalah bangaimana membawa makanan pulang yang mereka anggap bertua (membawa keberuntungan). Slametan diartikan derupa bentuk konsep dan upacara ritual yang selanjutnya di artikan dalam makna luas, yakni menghasilkan penciptaan kata, tertib, aman (keselamatan).

\section{Slametan dan Salamah dalam Islam}

Kata selamat berasal dari kata "salam" yaitu berasal dari salima-yaslamusalaman-salamat (h) berarti selamat, bebas, menerima, rela (puas), damai. Terdapat 155 ayat yang secara derivatif berasal dari kata salima. QS. 7: 46, "Di antara keduanya ada batas, di atas a'raf itu ada orang yang mereka kenal, masing-masing dengan tanda mereka. Dan mereka menyeru penduduk surga dengan 'salamun alaikum'...". Kata salamun alaikum memiliki arti keselamatan dan rasa aman selalu menyertai kalian (penduduk surga) Selanjutnya, Quraish Shihab menjelaskan kata salam berarti luput dari kekurangan, kerakusan, dan aib. Kata selamat diucapkan, misalnya jika terjadi hal-hal yang tidak diinginkan, tetapi kejadian tersebut tidak mengakibatkan pada kekurangan atau kecelakaan. Salam atau damai yang demikian adalah "damai positif" dan juga "damai aktif", yakni bukan saja terhindar dari keburukan, tetapi lebih dari itu, dapat meraih kebajikan atau kesuksesan. 
Dalam duniah yang ada pada saat ini, semua mahluk yang menghuninya akan berangan-angan hidup dalam Kedamaian, keamanan, dan kesentausaan hal ini merupakan cita-cita dan tujuan setiap makhluk hidup. Oleh karena itu, Allah SWT mengajak hambaNya ke negeri yang damai (dar al-salam) (QS. Yunus: 25). Allah sendiri adalah pangkalan kedamaian, keselamatan, dan kesentausaan (QS. al-Hasyr: 23). Tanpa adanya al-Salam (Allah) atau tanpa salam (kedamaian jiwa manusia), maka semuanya akan kacau, rusak, bahkan kehidupan akan berhenti.

Menyikapi makna dalam ayat-ayat diatas dapat dipahami bahwa, dari keyakinan akan keesaan Tuhan, pada gilirannya melahirkan kedamaian dan ketentraman yang mewujudkan keseimbangan antara hubungan dengan Sang Pencipta dan juga dalam hubungan sesama manusia. Sebaliknya, pelanggaran dan pengingkaran pada Tuhan akan melahirkan kekacauan, ketidakpastian, kegelisahan, dan ketakutan. Hal ini akan bermuara pada rasa kebersalahan yang tingggi dalam diri manusia, biasanya manusia yang seperti ini akn jauh dari ketenangan jiwa. Hal inilah yang melatar belakangi manusia mencari ketenangan atau keselamatan.

Gambaran-gambaran ini, dapat dilihat dari segi sejarah kehiduan manusia, sebagaiman yang dilukiskan oleh Allah Swt dalam Al-Qur,an bahwa manusia yang melakukan apa-apa yang dilarang oleh Allah atau sang Pencipta bentuk lawan kata dari ke-Islam-an sebagai wujud dari sifat zalim telah terjadi dallam pentas sejarah yang berujung pada dekradasi dan kejatuan "status" seperti yang dialami oleh Nabi Adam AS, yang mana atas perbuatan yang dilarang Allah dilakukannya maka penderitaan yang dialaminya adalah diturunkan dari syurga, pada kisa Nabi Yunus AS yang menderita hidup dalam perut ikan. Hal ini adalah gambaran yang terdapat dalam Al-Qur'an atas jawaban apa yang kita wujudkan dalam tingkah laku nya.

Meskipun dengan peristiwa-peristiwa tersebut pada akhirnya mereka menemukan kembali kepatuhan dan kepasrahan mereka, sekaligus menemukan keselarasan, keseimbangan, ketenangan, dan kedamain jiwa. Peristiwa yang dialami oleh para nabi sebagaimana disebut dalam Al-Qur, an, paling tidak memiliki dua maksud yaitu:

1. Peristiwa (kekufuran) tersebut menunjukkan adanya kebebasan diri untuk memilih. Artinya, manusia sebagai hamba Tuhan dilengkapi dengan potensi untuk bebas memilih antara patuh atau ingkar.

2. Pelajaran tentang transformasi kesadaran. Kesadaran diperoleh melalui pengalaman, yang sekarang mungkin dapat disebut trial and error, tetapi tetap pada pendirian bahwa pengalaman tersebut memiliki tambatan yang kuat, yakni Tuhan.

Dari maksud-maksud tersebut, berbeda dengan kekufuran sepanjang masa sebagaimana di alami oleh Fir'aun. Pelajaran yang dapat dipetik dari kisah kehidupan Fir'aun adalah "nihilis", yakni dapat disebut sebagai "kekosongan ruhani ketuhanan", sekalipun dia menyebut dirinya Tuhan. Fir'aun pada dasarnya dibutakan atas kekuasaan yang ada pada dirinya, sehingga terlupakan bahwa ada yang berkuasa atas yang dia miliki, 
kekosongan dalam dirinya menyebapkan Fir'aun takut akan kematian, merasa dirinya akan hidup untuk selamanya. Pengingkaran Fir'aun berakhir dibayar dengan social cost yang sangat mahal, yakni keterkungkungan, penindasan, serta penistaan citra kemanusiaan. Yang hal ini dapat kita lihat dari mumi Fir'aun di Mesir. Ini menunjukkan wujud dari siksaan yang dialami manusia.

Salamat menurut Ibn Araby sebagaimana terdapat dalam karya William C. Chittick (Kusumohamidjojo, 2010, h. 144), bahwa keselamatan dapat dicapai melalui "adaptasi" atau proses penyelarasan dengan qadr (ukuran-ukuran) Tuhan. Qadr Tuhan adalah Syari'ah. Jika seseorang menyimpang dari qadr (syari'ah) tersebut, maka pada dasarnya tidak ada keselamatan bagi dirinya.

Dari penjelasan diatas dapat digambarkan bahwa, Tuhan yang dimaksud Ibn Araby adalah Tuhan sebagaimana yang dikonsepsikan dalam Al-Qur,an yakni sebagai pencipta, pemelihara, dan pengatur kehidupan. Jika disandingkan dengan pemahaman masyarakat Jawa pra-Islam, terutama pada zaman animisme dan dinamisme, kepercayaan mereka ada pada kekuatan-kekuatan lain selain dirinya. Kekuatan di luar dirinya dinyatakan sebagai Tuhan, termasuk ruh nenek-moyang, kekuatan magis benda-benda, dan lain sebagainya, yang di dalam Islam adalah sebagai makhluk Tuhan. Hal ini dilakukan karena kesadaran mereka akan kelemahan yang dialaminya, ketidak mampuan dalam melindungi diri sendiri, bahkan buah hasil dari pemikiran yang didasarkan atas kegelisaan dalam jiwa.

Islam menganjurkan pemeluknya untuk mempercayai hal-hal ghaib (hal-hal yang kasat mata), seperti jin, malaikat, roh, dan makhluk ghaib lain. Makhluk-makhluk ghaib sebagaimana dijelaskan dalam al-Qur'an memiliki potensi (kemampuan) tertentu yang mungkin tidak dimiliki oleh jenis makhluk lainnya. Akan tetapi, kepercayaan dan keimanan tersebut menandaskan bahwa potensi (kekuatan) tersebut adalah potensi pemberian Allah, Tuhan semesta alam. Dengan kata lain, tidak ada kekuatan apapun jika tidak diberi oleh Allah. Gambaran ini didasarkan atas kesadaran umat manusia dalam perjalanan yang panjang atau mengalami proses sejarah yang bermasa-masa.

Dalam Islam dasar-dasar penghargaan sesama makhluk Tuhan diperbolehkan selagi tidak menjurus pada penuhanan (menjadikan Tuhan). Sesama manusia dianjurkan saling menghargai dan dilarang menyakiti. Demikian juga terhadap makhluk lain, termasuk kepada hewan, bahkan makhluk ghaib lain. Dalam Islam yang sangat dilarang adalah menuhankan bukan Tuhan dan me-makhluk-kan Tuhan. Artinya penyembahan pada bukan Allah adalah dilarang dalam Islam, atau bisa dikatakan Musrik, sebesar apapun kekuatan yang dimilikinya pada dasarnya ada yang lebih besar lagi yaitu Allah Swt. Dalam al-Quran, Allah adalah nama Tuhan umat Nabi Muhammad Saw, selain menuhankan Allah Swt, berarti menuhankan selain Tuhan. Memberi perlakukan khusus seperti perlakuan kepada Tuhan (penyembahan dan pengorbanan) adalah perbuatan syirik, yang disebut sebagai dosa besar. 
Wujud rai sesajenan dalam masyarakat Jawa, digambarkan Islam dalam bentuk bershadaqah. Shadaqah berasal dari kata shadaqa-yasduqu-shidqan, shadaqah, yang berarti nyata, benar, persahabatan. Secara terminologis, shadaqah adalah pemberian dari seseorang kepada orang lain dengan tanpa pamrih apa-apa kecuali karena "persahabatan" dan ridha Allah Swt. Pemberian shadaqah didasarkan pada ketulusan hati dan keihlasan tas rizki yang didapatkanya dari Allah Swt. Hal ini terutama shadaqah diberikan kepada orang yang tepat (yang paling sangat membutuhkan). Bershadaqah selain dari wujud berbagi rizki hal ini juga menghindarkan manusia azab Allah. Tala bala', berasal dari kata tala, dan bala', artinya adalah mencegah musibah, kemadharatan atau murkah dari Allah Swt.

Istilah shadaqah juga terkadang dihubungkan dengan istilah syukuran. Hal ini karena dalam acara syukuran seringkali dihidangkan berbagai makanan sebagai sedekah (shadaqah). Memang shadaqah tidak terbatas pada pemberian yang sifatnya materi, tetapi juga imateri seperti mendoakan, ramah, senyum, dan lainnya.

Dalam ajaran Islam, shadaqah memiliki posisi sangat penting sehingga lebih dari 25 kali disebut dalam al-Qur'an, dan lebih dari 500 Hadis yang menganjurkan untuk bershadaqah dalam berbagai bentuk dan variasinya. Lebih khusus disebut dalam sebuah Hadis yang sangat terkenal intinya adalah ada tiga perbuatan yang akan tidak akan putus sekalipun pelakunya telah meninggal dunia, yakni shadaqah jariyah, ilmu yang bermanfaat, dan anak shalih yang mendoakan orangtuanya (Gazalba, 1975, h. 17-19).

Orang yang gemar shadaqah akan timbul pada dirinya rasa saling memiliki, hal ini sulit untuk dimiliki orang lain. Yang paling penting dalam shadaqah akan meningkatkan rasa persaudaraan antar sesama. Wujud dari kesosialan ini akan berdampak pada kemasyarakatan. Ini menunjukkan begitu indahnya Islam dalam mengajarkan suatu persaudaraan dan menyempurnakan kebudayaan lokal dalam masyarakat Indonesia.

\section{Kesimpulan}

Tradisi slametan berakar dari budaya asli Jawa yaitu diawali dengan bekeyakianan animisme dan dinamisme yang pada dasarnya adalah keyakinan nenek moyang, dan selanjutnya dihidupkan dan diperkaya oleh budaya Hindu dan Buddha yang mempercayai adanya dewa-dewa yang berwujud benda-benda dan kejadian alam. Masuknya Islam di Jawa menggunakan pola "damai" dengan persuasi sehingga masih terdapat simbolsimbol budaya masa lalu yaitu animisme-dinamis, Hindu-Buddha yang masih menjadi "pola" pikir dan paradigma masyarakat Jawa.

Slametan adalah konsep universal yang di setiap tempat pasti ada dengan nama yang berbeda dan bermacam cara pula. Hal ini karena kesadaran akan diri yang "lemah" di hadapan kekuatan-kekuatan di luar diri manusia. Di Jawa Kuno, kekuatan diri adalah kekuatan benda dan ruh nenek-moyang yang pada saat Islam datang ditranformasikan pada selamat dari kekuatan Tuhan yang dapat merugikan diri manusia. Dengan 
Ryko Adiansyah

Persimpangan Antara Agama dan Budaya

(Proses Akulturasi Islam dengan Slametan dalam Budaya Jawa)

berkeyakian selamat melalui pemagaran (perlindungan) dari Tuhan maka manusia dapat menyadarinya akan kelemahan yang selama ini diyakininya. Namun pada dasarnya keyakinan yang ada dan berkembang akan tumbuh dan berkembang secara berlahan, dan tidak bisa dihilangkan dengan berputarnya zaman. 


\section{Daftar Pustaka}

Jurnal Harmoni (2011). Agama dan Budaya Dalam Dinamika Kehidupan Masyarakat. Dalam Endang Turmudzi (2010) "Perkembangan Sufisme dan Kebangkitan Tradisionalisme" Jakarta: Puslitbang Kehidupan Keagamaan Badan Litbang dan Diklat Kementrian Agama RI. Vol. X.No 4 edisi Okt-Des.

Harmoni (2010). Agama dan Budaya Dalam Dinamika Kehidupan Masyarakat. Dalam Amani Lubis. (2011) "Presepsi Agama Dalam Budaya di Yogyakarta". Jakarta: Puslitbang Kehidupan Keagamaan Badan Litbang dan Diklat Kementrian Agama RI. Edisi Okt-Des. Vol. X. No. 4.

Forum Rektor Indonesia Simpul Jawa Timur (2003). Hidup Berbangsa dan Ekita Multikultural. Surabaya: Universitas Surabaya.

Hermanto, Winarno. (2011).Ilmu Sosial dan Budaya Dasar. Jakarta: Penerbit Bumi Aksara.

Kessing, Roger, M., 1992, Antropologi Budaya suatu persepektif Kontemporer, jilid 2, terj: Samuel Gunawan, Jakarta: Erlangga. Koentrajaningrat (Ed), 1975, Manusia dan Kebudayaan di Indonesia, Jakarta: Jambatan.

Sri Wahyuni, Niniek. Dkk. (2007). Manusia dan Masyarakat. Jakarta: Ganeca Exact. 3.

Mubarak, Achmad. (2004). Nasionalis Religius Jati Diri Bangsa Indonesia. Jatiwaringin: PT.Bina Rena Pariwara.

Rachels. (2004). Filsafat Moral. Judul asli The Elements of Moral Philosophy, A. Sudiarja (terj), Yogyakarta: Kanisius.

A.R Tilaar. (2002). Pendidikan, Kebudayaan, dan Masyarakat Madani Indonesia. Bandung: Remaja Rosdakarya.

Kusumohamidjojo. (2009). Islam dan Budaya Lokal. Yogyakarta: Teras.

Kusumohamidjojo. (2010). Filsafat Kebudayaan; Proses Realisasi Manusia. Yogyakarta: Jalasutra.

Sidi Gazalba. (1975). Mesjid: Pusat Ibadat dan Kebudayaan Islam.Jakarta: Pustaka Antara. 